\title{
Effect of phosphorus on iron toxicity: photosynthetic and antioxidant responses of rice cultivars
}

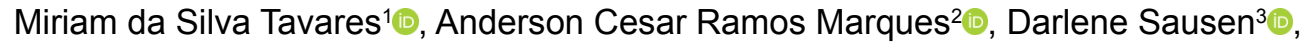 \\ Ruziele de Quadros Sandri Strauss ${ }^{2} \oplus$, Aniélen Dutra da Silva²®, Leticia Frizzo Ferigolo²®, \\ Camila Peligrinotti Tarouco ${ }^{2} \odot$, Fernando Teixeira Nicoloso² \\ ${ }^{1}$ Universidade Estadual de Goiás, Posse, GO, Brasil. E-mail: myriann_silva@hotmail.com \\ 2 Universidade Federal da Santa Maria, Santa Maria, RS, Brasil. E-mail: acrmarques@hotmail.com.br; ruziele@gmail.com; anielen.dutra@gmail.com; leticiafrizzo@usp.br; \\ milatarouco@gmail.com; fftnicoloso@yahoo.com \\ ${ }^{3}$ Universidade Federal do Rio Grande do Norte, Macaíba, RN, Brasil. E-mail: darlene_sn@yahoo.com.br
}

ABSTRACT: Iron (Fe) toxicity is a problem that affects many rice areas in lowland environments. The aim of this study was to investigate, through photosynthetic and antioxidant responses, the effect of phosphorus $(P)$ nutrition as a mitigator of iron $(\mathrm{Fe})$ toxicity in rice cultivars. The experimental design used was in randomized blocks, with four replications Three rice cultivars $(\mathrm{Br} /$ Irga 409, Irga 424, and Irga 425) were exposed to two concentrations of $\mathrm{Fe}$ (2 and $\left.200 \mathrm{mg} \mathrm{L}^{-1}\right)$ combined with two concentrations of $P\left(2.5\right.$ and $\left.15 \mathrm{mg} \mathrm{L}^{-1}\right)$ in a nutrient solution, for 60 days. The results show that the excess of Fe reduced the root dry matter of all cultivars, but only the cultivar Br/lrga 409 showed a decrease in the shoot dry matter. The antioxidant enzymatic activity was not efficient to attenuate the toxicity by Fe due to the higher lipid peroxidation and decrease in the net $\mathrm{CO}_{2}$ assimilation rate. The cultivar Irga 425 showed greater tolerance to conditions of toxicity by Fe when associated with the increase in $P$ availability, with high photosynthetic responses and enzymatic activity (superoxide dismutase). The cultivar Br/lrga 409 showed greater sensitivity to toxicity by Fe compared to other cultivars.

Key words: antioxidant system; $\mathrm{CO}_{2}$ assimilation; mineral nutrition; Oryza sativa L.

\section{Efeito do fósforo na toxicidade por ferro: respostas fotossintéticas e antioxidante}

\section{de cultivares de arroz}

RESUMO: A toxicidade de ferro ( $\mathrm{Fe}$ ) é um problema que afeta muitas áreas de arroz cultivadas em ambientes de terras baixas. Objetivou-se investigar, através de respostas fotossintéticas e antioxidantes, o efeito da nutrição de fósforo $(P)$ como mitigador da toxidez de ferro ( $\mathrm{Fe}$ ) em cultivares de arroz. O delineamento experimental utilizado foi em blocos casualizados, com quatro repetições. Três cultivares de arroz (Br/lrga 409, Irga 424, Irga 425) foram expostas às concentrações de Fe (2 e $\left.200 \mathrm{mg} \mathrm{L}^{-1}\right)$ combinadas com as concentrações de $\mathrm{P}\left(2,5\right.$ e $\left.15 \mathrm{mg} \mathrm{L}^{-1}\right)$ em solução nutritiva, durante 60 dias. Os resultados mostram que 0 excesso de Fe reduziu a massa seca de raiz de todas as cultivares, porém apenas a cultivar Br//rga 409 reduziu a massa seca de parte aérea. A atividade enzimática antioxidante não foi eficiente para atenuar a toxidez por Fe devido à maior peroxidação lipídica e reduções na taxa de assimilação líquida de $\mathrm{CO}_{2}$. A cultivar Irga 425 demonstrou maior tolerência a condições de toxidez por $\mathrm{Fe}$, quando associado ao aumento na disponibilidade $\mathrm{P}$, com elevadas respostas fotossinéticas $e$ atividade enzimática (superóxido dismutase). A cultivar Br/lrga 409 apresentou maior sensibilidade à toxidez por Fe em relação às demais cultivares.

Palavras-chave: sistema antioxidante; assimilação de $\mathrm{CO}_{2}$; nutrição mineral; Oryza sativa L. 


\section{Introduction}

The interaction of metals with organic compounds are essential in order to maintain cellular homeostasis in all living beings (Briat et al., 2010). Iron (Fe) is an essential element for several biochemical and physiological processes in plants (Vigani et al., 2013). In photosynthesis, this element is a cofactor of the cytochrome complex, of the photosystems (PSII and PSI), and participates in the biosynthesis of chlorophyll (Yadavalli et al., 2012). It is also essential for the synthesis of DNA (ribonucleotide reductase), lipids (lipoxygenase), hormones (1- aminocyclopropane-1 carboxylic acid (ACC) oxidase), and antioxidant enzymes (superoxide dismutase) (Curie et al., 2009).

In soils under aerobic conditions, Fe is found in its insoluble form, bound to secondary soil minerals, and in the form of $\mathrm{Fe}^{3+}$ In anaerobic environments, this element is reduced to $\mathrm{Fe}^{2+}$, becoming more soluble (Pezeshki \& Delaune, 2012). It is estimated that around $12-100 \%$ of flooded rice paddies present problems of Fe toxicity (Sahrawat, 2010). In this context, Fe toxicity affects the production of rice grains in areas of West Africa, Asian Southeast, Madagascar, and Southern Brazil (Becker \& Asch, 2005; van Oort, 2018). In Brazil, losses from 15 to $20 \%$ were already reported by Andrade et al. (2015).

Due to the strong chemical reactivity, the excess of $\mathrm{Fe}$, through Fenton's reaction, promotes the formation of reactive oxygen species (ROS), especially the hydroxyl radical. These radicals are highly toxic and responsible for the peroxidation of lipids and proteins (Briat et al., 2010). In this context, the plant cells possess enzymatic mechanisms that eliminate or reduce the harmful effects of ROS, such as the superoxide dismutase, ascorbate peroxidase, catalase, and guaiacol peroxidase, as well as non-enzymatic mechanisms, through compounds such as glutathione, ascorbic acid, carotenoids, and tocopherols (Yadavalli et al., 2012).

Changes in $\mathrm{Fe}$ homeostasis can also influence the availability of other elements (Jeong \& Guerinot, 2009), such as phosphorus (P) (Howeler, 1973). Phosphorus is not directly involved in oxidation and reduction reactions in flooded soils, but due to the compatibility between reducible compounds, this element is deeply affected (Shahandeh et al., 2003). In acid soils, there is a predominance of $\mathrm{P}$ associated with $\mathrm{Fe}$ and aluminum, although with the flooding and subsequent reduction of ferric into ferrous compounds, there is a release of the $\mathrm{P}$ retained by adsorption or specific chemical bond. Parallel to that, with the increase in the reduction intensity, there is an increase of the $\mathrm{pH}$, consequently affecting the solubility of several compounds, such as the concentration of $P$, which begins to decrease as a consequence of the precipitation of ferrous phosphate and adsorption to $\mathrm{Fe}$ oxides (Sousa et al., 2006).

$P$ is essential for several vital metabolic processes since it acts as a component of plant membranes and intermediate compounds of photosynthesis and respiration (Huang et al., 2008). In photosynthesis, reductions in $P$ availability promote a decrease in the regeneration of ribulose-1,5-biphosphate in the Calvin Cycle, in response to the reduction in the synthesis of ATP (Pieters et al., 2001). Studies demonstrate that the concentrations of cytoplasmic $P$ are essential for the proper functioning of antioxidant enzymes (Ahn et al., 2005). Therefore, an adequate $P$ supply can increase the exclusion of Fe from reactions in the roots and, thus, reduce its absorption and translocation to the shoot part of the plant (Silveira et al., 2007), mitigating the effects of Fe toxicity. In this manner, this study aimed to investigate, through photosynthetic and antioxidant responses, the effect of phosphorus $(P)$ nutrition as a mitigator of iron (Fe) toxicity in rice cultivars.

\section{Materials and Methods}

Three rice cultivars were grown under plant nursery conditions, in the municipality of Santa Maria (29 $42^{\prime} 56.44^{\prime \prime}$ S and $\left.53^{\circ} 43^{\prime} 12.57^{\prime \prime}\right)$, state of Rio Grande do Sul, Brazil, from September 2015 to December 2015.

The plant materials were selected for presenting different responses to Fe toxicity, with the cultivars IRGA 424 and IRGA 425 being considered tolerant, whereas the BR/IRGA 409 is considered sensitive. The seeds were initially moistened with distilled water, remaining at $25^{\circ} \mathrm{C}$ and in the dark for 24 hours, on Petri dishes. After this period, the pre-germinated seeds were transferred to partially-closed boxes covered with germitest ${ }^{\circledR}$ paper, being irrigated with distilled water for 7 days, within climatized plant growth chambers.

After germination, 5 seedlings were transferred to the experimental units, constituted of $7 \mathrm{~kg}$ pots filled with sand. The pots received irrigation with a nutritive solution up to $80 \%$ of field capacity. The nutritive solution used was defined by Yoshida et al. (1976), with slight modifications, in which different Fe concentrations were tested, using as a source the EDTA-FeSO $\mathrm{S}_{4} .7 \mathrm{H}_{2} \mathrm{O}$, as well as different $\mathrm{P}$ concentrations, using as a source the $\mathrm{NaH}_{2} \mathrm{PO}_{4} \cdot 7 \mathrm{H}_{2} \mathrm{O}$. The nutritive solution used to acclimatize the plants until the $\mathrm{V} 4$ stage was constituted of: $40 \mathrm{mg} \mathrm{L}^{-1} \mathrm{NH}_{4} \mathrm{NO}_{3}, 2.5 \mathrm{mg} \mathrm{L}^{-1} \mathrm{NaH}_{2} \mathrm{PO}_{4} 2 \mathrm{H}_{2} \mathrm{O}, 40 \mathrm{mg} \mathrm{L}^{-1} \mathrm{~K}_{2} \mathrm{SO}_{4^{\prime}}$ $40 \mathrm{mg} \mathrm{L}^{-1} \mathrm{CaCl}_{2}, 40 \mathrm{mg} \mathrm{L}^{-1} \mathrm{MgSO}_{4}$. $7 \mathrm{H}_{2} \mathrm{O}, 0.5 \mathrm{mg} \mathrm{L}^{-1} \mathrm{MnCl}_{2} .4 \mathrm{H}_{2} \mathrm{O}$, $0.05 \mathrm{mg} \mathrm{L}^{-1}\left(\mathrm{NH}_{4}\right)_{6} \mathrm{MO}_{7} \mathrm{O}_{24} \cdot 4 \mathrm{H}_{4} \mathrm{O}, 0.2 \mathrm{mg} \mathrm{L}^{-1} \mathrm{H}_{3} \mathrm{BO}_{3^{\prime}} 0.01 \mathrm{mg}$ $\mathrm{L}^{1} \mathrm{ZnSO}_{4} \cdot 7 \mathrm{H}_{2} \mathrm{O} 0.01 \mathrm{mg} \mathrm{L}^{-1} \mathrm{CuSO}_{4} \cdot 5 \mathrm{H}_{2} \mathrm{O}$, and $2 \mathrm{mg} \mathrm{L}^{-1}$ EDTA$\mathrm{Fe}_{2} \mathrm{SO}_{4} \cdot 7 \mathrm{H}_{2} \mathrm{O}^{2}$

When the plants emitted the fourth leaf (V4), the nutritive solution was provided until the formation of a $3 \mathrm{~cm}$ water depth, also adding the treatments: Fe excess (200 $\left.\mathrm{mg} \mathrm{L}^{-1} \mathrm{Fe}\right)$, Fe control $\left(2 \mathrm{mg} \mathrm{L}^{-1}\right)$, combined with different $\mathrm{P}$ concentrations ( 2.5 and $15 \mathrm{mg} \mathrm{L}^{-1}$ ), thus obtaining the following nutritional concentrations: $2.5 \mathrm{mg} \mathrm{L}^{-1}$ of $\mathrm{P}$ and $2 \mathrm{mg} \mathrm{L}^{-1}$ of $\mathrm{Fe}$ [Fe/P]; 2.5 $\mathrm{mg} \mathrm{L}^{-1}$ of $\mathrm{P}$ and $200 \mathrm{mg} \mathrm{L}^{-1}$ of $\mathrm{Fe}[+\mathrm{Fe} / \mathrm{P}] ; 15 \mathrm{mg} \mathrm{L}^{-1}$ of $\mathrm{P}$ and $2 \mathrm{mg} \mathrm{L}^{-1}$ of $\mathrm{Fe}[\mathrm{Fe} /+\mathrm{P}], 15 \mathrm{mg} \mathrm{L}^{-1}$ of $\mathrm{P}$ and $200 \mathrm{mg} \mathrm{L}^{-1}$ of $\mathrm{Fe}$ $[+\mathrm{P} /+\mathrm{Fe}]$. The solution was added weekly in order to maintain the water depth, which was kept until 60 days after planting. The experimental design was in randomized blocks, using a $3 \times 2 \times 2$ factorial scheme with three cultivars (Br/Irga 409, Irga 424, and Irga 425), two P concentrations (2.5 and 15 mg $\left.\mathrm{L}^{-1}\right)$ and two Fe concentrations, in 4 replications with 5 plants each, totaling 20 plants per treatment. 
At 60 days after planting (DAP), the gas exchange measurements were made in the middle third of the fullyexpanded leaves with an $\mathrm{LI}^{-\mathrm{COR}^{\circledR}}{ }^{\circledR}$ handheld Infrared Gas Analyzer (IRGA), model LI-6400 XT, using photosynthetic radiation of $1,500 \mu \mathrm{mol} \mathrm{m} \mathrm{m}^{-2} \mathrm{~s}^{-1}$ and a $\mathrm{CO}_{2}$ concentration of $400 \mu \mathrm{mol} \mathrm{mol}^{-1}$. Two plants were used per replication of each treatment, and the readings were performed from 8 a.m. to 11 a.m. by determining the following variables: net $\mathrm{CO}_{2}$ assimilation rate (A), stomatal conductance (Gs), intercellular $\mathrm{CO}_{2}$ concentration ( $\mathrm{Ci}$ ), and carboxylation efficiency of Rubisco $(\mathrm{A} / \mathrm{Ci})$. The units expressed as follows: $\mathrm{A}\left(\mathrm{mmol}\right.$ de $\left.\mathrm{CO}_{2} \mathrm{~m}^{-2} \mathrm{~s}^{-1}\right)$, $\mathrm{Gs}\left(\mathrm{mol} \mathrm{de} \mathrm{H}_{2} \mathrm{O} \mathrm{m}^{-2} \mathrm{~s}^{-1}\right), \mathrm{Ci}\left(\mu \mathrm{mol} \mathrm{CO} \mathrm{mol}^{-1}\right)$, and $\mathrm{A} / \mathrm{Ci}$.

The pigment concentrations (chlorophylls and carotenoids) were determined according to the methodology of Hiscox \& Israelstam (1979) and estimated according to the formula of Lichtenthaler (1987). $0.05 \mathrm{~g}$ of fresh material was used for the determination of chlorophyll-a, chlorophyll-b, and carotenoids, and the solution absorbance was measured at the wavelengths of 663,645 , and $470 \mathrm{~nm}$, respectively, using a spectrophotometer. The pigment concentration was expressed in $\mathrm{mg} \mathrm{g}^{-1} \mathrm{MF}$ (fresh matter).

The hydrogen peroxide concentration $\left(\mathrm{H}_{2} \mathrm{O}_{2}\right)$ in the shoot part was determined according to the methodology of Loreto \& Velikova (2001), using $0.1 \mathrm{~g}$ of tissue that was homogenized with $2.0 \mathrm{~mL}$ of $0.1 \%$ trichloroacetic acid (TCA). The concentration of $\mathrm{H}_{2} \mathrm{O}_{2}$ was obtained by the absorbance of the reaction with a $10 \mathrm{mM}$ potassium phosphate buffer solution ( $\mathrm{pH}$ 7.0) and $1 \mathrm{M}$ potassium iodide at $390 \mathrm{~nm}$, and by comparison with the standard curve. The $\mathrm{H}_{2} \mathrm{O}_{2}$ concentration was expressed in $\mu \mathrm{mol} \mathrm{g}^{-1} \mathrm{MF}$.

The lipid peroxidation was estimated by the accumulation of malondialdehyde (MDA) as the final product of lipid peroxidation through the reaction with thiobarbituric acid (TBA), according to El-Moshaty et al. (1993). $0.5 \mathrm{~g}$ of the sample was homogenized in $4.0 \mathrm{ml}$ of the TFK citrate-phosphate buffer (0.2, $\mathrm{M} \mathrm{pH} \mathrm{6.5),} \mathrm{after} \mathrm{which} \mathrm{the} \mathrm{samples} \mathrm{were} \mathrm{centrifuged} \mathrm{in} \mathrm{a}$ refrigerated centrifuge at $4{ }^{\circ} \mathrm{C}$ for $15 \mathrm{~min}$, at 20,000 g. For the determination of MDA, $1.5 \mathrm{~mL}$ aliquots from the supernatant fraction were added to an equal volume of thiobarbituric acid (TBA) at $0.5 \%(\mathrm{p} / \mathrm{v})$ and trichloroacetic acid (TCA) at 20\% (p/v) and incubated in a water bath at 95 ㅇ $\mathrm{C}$ for $40 \mathrm{~min}$. The reaction was stopped in an ice bath for $15 \mathrm{~min}$. After the centrifugation at 10,000 $\mathrm{g}$ for $5 \mathrm{~min}$, the absorbance was detected at $532 \mathrm{~nm}$, discounting the interspecific absorbance at $600 \mathrm{~nm}$. The MDA concentration was calculated and the results were expressed in $\mathrm{nM}$ MDA $\mathrm{mg}^{-1}$ protein.

For the determination of the enzymatic activity, frozen samples containing $0.5 \mathrm{~g}$ of tissue previously macerated in liquid nitrogen were used. The samples were homogenized using $3 \mathrm{~mL}$ of a sodium phosphate buffer solution $(0.05 \mathrm{M}$, $\mathrm{pH} 7.8)$, including EDTA $1 \mathrm{mM}$ and Triton $X$ at $1 \%(\mathrm{p} / \mathrm{v})(\mathrm{Zhu}$ et al., 2004). The supernatant was used for the evaluation of the activity of the superoxide dismutase (SOD) and guaiacol peroxidase (POD) enzymes. The activity of the SOD enzyme was determined according to Giannopolitis \& Ries (1977). The POD was determined according to Zeraik et al. (2008). The activities of the SOD and POD enzymes were expressed in $U$ $\mathrm{mg}^{-1}$ of protein and mmol tetraguaiacol $\mathrm{min}^{-1} \mathrm{mg}^{-1}$ of protein, respectively.

After 60 days, the samples were separated into shoot and root parts, being then placed in paper bags and subjected to drying in a forced-air oven at $75{ }^{\circ} \mathrm{C}$ for $48 \mathrm{~h}$ in order to determine the dry mass of roots (MSR) and shoot (MSPA) through weighing in a precision balance. The production of MSPA and MSR was expressed in g plant $^{-1}$. The differences in the concentrations of MDA, growth, chlorophyll concentration, gas exchanges, and activity of antioxidant enzymes were analyzed by analysis of variance and by the Scott Knott test, with a $5 \%$ significance level, using the SISVAR statistical software.

\section{Results and Discussion}

The variables of net $\mathrm{CO}_{2}$ assimilation rate $(A)$ and Rubisco carboxylation efficiency $(\mathrm{A} / \mathrm{Ci})$ presented responses to the interaction between the studied factors of cultivars $x$ iron concentrations ( $\mathrm{Fe}$ ) $x$ phosphorus concentrations $(\mathrm{P})$ (Table 1 ).

At low Fe concentration ( $2 \mathrm{mg} \mathrm{L}^{-1}$ ) associated WITH the low concentration of $P\left(2.5 \mathrm{mg} \mathrm{L}^{-1}\right)$, the cultivars Irga 425 and $\mathrm{Br}$ / Irga 409 presented higher A when compared to the cultivar Irga 424. Regardless of the Fe concentration tested, the cultivar Irga 425 presented higher A than the cultivar $\mathrm{Br} / \mathrm{Irga}$ 409 with the increase in the $\mathrm{P}$ concentration in the nutritive solution (Table 1).

When comparing the $A$ in the Fe control treatment (2 $\left.\mathrm{mg} \mathrm{L}^{-1}\right)$, at different $P$ concentrations ( 2.5 and $\left.15 \mathrm{mg} \mathrm{L}^{-1}\right)$, it is verified that the cultivars Irga 424 and Irga 425 presented increments in the value of the variable, with the increase in the concentration of $P$ in the nutritive solution (Table 1). However, with the excess of Fe associated with the high concentration of $\mathrm{P}$, only the cultivar Irga 425 presented increases of $10.93 \%$

Table 1. $\mathrm{CO}_{2}$ assimilation rate $(\mathrm{A})$ and rate of Rubisco carboxylation efficiency $(\mathrm{A} / \mathrm{Ci})$ of three rice cultivars $(\mathrm{Br} /$ Irga 409, Irga 424, and Irga 425) grown under different Fe concentrations $\left(2,200 \mathrm{mg} \mathrm{L}^{-1}\right)$ and $\mathrm{P}\left(2.5,15 \mathrm{mg} \mathrm{L}^{-1}\right)$ in the nutritive solution.

\begin{tabular}{|c|c|c|c|c|}
\hline & \multicolumn{2}{|c|}{$\mathrm{Fe}\left(2 \mathrm{mg} \mathrm{L}^{-1}\right)$} & \multicolumn{2}{|c|}{$+\mathrm{Fe}\left(200 \mathrm{mg} \mathrm{L}^{-1}\right)$} \\
\hline & $\begin{array}{c}P \\
\left(2.5 \mathrm{mg} \mathrm{L}^{-1}\right)\end{array}$ & $\begin{array}{c}+P \\
\left(15 \mathrm{mg} \mathrm{L}^{-1}\right)\end{array}$ & $\begin{array}{c}P \\
\left(2.5 \mathrm{mg} \mathrm{L}^{-1}\right)\end{array}$ & $\begin{array}{c}+P \\
\left(15 \mathrm{mg} \mathrm{L}^{-1}\right)\end{array}$ \\
\hline \multicolumn{5}{|c|}{$\mathrm{A}\left(\mathrm{mmol}\right.$ of $\left.\mathrm{CO}_{2} \mathrm{~m}^{-2} \mathrm{~s}^{-1}\right)$} \\
\hline $\mathrm{Br} / \mathrm{Irga} 409$ & 17.14 Аa $\alpha$ & 16.24 Ba $\alpha$ & $12.55 \mathrm{Aa} \beta$ & $13.04 \mathrm{Ba \beta}$ \\
\hline Irga 424 & $12.34 \mathrm{Bb} \alpha$ & 1750 Aa $\alpha$ & 14.11 Aa $\alpha$ & $13.89 \mathrm{Ba} \beta$ \\
\hline Irga 425 & $15.51 \mathrm{Aba}$ & $18.74 \mathrm{Aa \beta}$ & 14.43 $\mathrm{Ab} \alpha$ & 21.04 Aa $\alpha$ \\
\hline \multicolumn{5}{|c|}{$\mathrm{A} / \mathrm{Ci}$} \\
\hline $\mathrm{Br} / \mathrm{Irga} 409$ & $0.050 \mathrm{Aa} \alpha$ & $0.050 \mathrm{Aa} \alpha$ & $0.046 \mathrm{Aa \beta}$ & $0.046 \mathrm{Ba} \alpha$ \\
\hline Irga 424 & $0.037 \mathrm{Ba} \beta$ & $0.051 \mathrm{Aa} \alpha$ & $0.061 \mathrm{Aa} \alpha$ & $0.049 \mathrm{Ba} \alpha$ \\
\hline Irga 425 & $0.052 \mathrm{Aa} \alpha$ & $0.055 \mathrm{Aa \beta}$ & $0.059 \mathrm{Aa} \alpha$ & $0.072 \mathrm{Aa} \alpha$ \\
\hline
\end{tabular}

Means followed by different letters differ significantly by the Scott Knott test at $5 \%$ of error probability. Uppercase letters compare cultivars within the same treatment $(\mathrm{P} / \mathrm{Fe}$ $+\mathrm{P} / \mathrm{Fe}, \mathrm{P} /+\mathrm{Fe},+\mathrm{P} /+\mathrm{Fe})$. Lowercase letters compare the same cultivar in the $\mathrm{P}$ treatments at the same concentration of $\mathrm{Fe}(\mathrm{P} / \mathrm{Fe},+\mathrm{P} / \mathrm{Fe} ; \mathrm{P} /+\mathrm{Fe},+\mathrm{P} /+\mathrm{Fe})$. Greek letters compare the same cultivars at different $\mathrm{Fe}$ concentrations and at the same $\mathrm{P}$ concentration $(\mathrm{P} / \mathrm{Fe}$, $\mathrm{P} /+\mathrm{Fe} ;+\mathrm{P} / \mathrm{Fe},+\mathrm{P} /+\mathrm{Fe})$. 
in $\mathrm{A}$ in relation to the plants subjected to Fe excess and low $\mathrm{P}$ concentration (Table 1).

Regardless of the $\mathrm{P}$ concentrations in the nutritive solution, the cultivar Br/Irga 409 was the most affected by Fe excess, presenting a reduction in $A$ when compared to the plants subjected to the control treatments. On the other hand, under Fe excess, the cultivar Irga 425 was the only that exhibited an increase in $A$ with the $P$ concentration increase in the nutritive solution (Table 1). According to Pandey et al. (2015), the photosynthetic capacity is often increased under high $\mathrm{CO}_{2}$ concentration and adequate $\mathrm{P}$ supply since they promote the modulation of enzymatic activities involved in carbon fixation, such as ribulose-1,5-bisphosphate carboxylase /oxygenase (Rubisco).

When exposed to low concentrations of $\mathrm{P}$ and $\mathrm{Fe}$ in the nutritive solution, the cultivars Irga 425 and Br/Irga 409 presented higher A/Ci when compared to the cultivar Irga 424 (Table 1). However, when subjected to $F$ excess associated with the increase in the concentration of $P$, only the cultivar Irga 425 presented higher $\mathrm{A} / \mathrm{Ci}$ in relation to the two other cultivars (Table 1 ).

Under Fe excess, associated with a low $\mathrm{P}$ concentration, the cultivar Br/Irga 409 presented a reduction in the $\mathrm{A} /$ $\mathrm{Ci}$ when compared to the plants subjected to the control treatment $[\mathrm{Fe} / \mathrm{P}]$. The cultivar Irga 425, under Fe excess associated to a high $\mathrm{P}$ concentration, presented an increase of $30.90 \%$ in the $\mathrm{A} / \mathrm{Ci}$ when compared to the plants subjected to the control treatment $[\mathrm{Fe} /+\mathrm{P}]$, a fact that was not observed in the remaining cultivars (Table 1$)$.

The stomatal conductance (Gs) variable presented a significant response for the isolated factor of cultivars and $\mathrm{Fe}$ concentrations. The intercellular $\mathrm{CO}_{2}$ concentration (Ci), in its turn, only presented a response to the isolated factor of $\mathrm{Fe}$ concentrations (Table 2).

In general, the alterations in the $\mathrm{A}$ and $\mathrm{A} / \mathrm{Ci}$ (Table 1 ) under Fe excess conditions were accompanied by reductions of $40 \%$ in stomatal conductance and $11.75 \%$ in the intercellular $\mathrm{CO}_{2}$ concentration $(\mathrm{Ci})$. The $\mathrm{Gs}$ differed between cultivars, observing the following order: Irga 425> Irga 424 > Br/Irga 409 (Table 2). These results corroborate with Majerus et al. (2009), who verified that the stress by Fe induced a decrease in the water potential of the leaf, and also caused reductions in the Gs.
Stomatal closure can indirectly cause a decrease in the transportation of electrons in the photochemical phase, consequently favoring photoinhibition and oxidative stress (Pereira et al., 2014). Abscisic acid (ABA) performs an essential function in stomatal regulation (Schroeder et al., 2001). In this manner, the abscisic acid ( $A B A$ ) may be involved in the stomatal limitation of photosynthesis as part of a cellular response to Fe excess and oxidative stress (Pereira et al., 2014).

The lipid peroxidation (MDA) responded only to the cultivar factor, with the lowest MDA concentration for the cultivar Irga 425 (Table 2). The concentration of chlorophyll-a ( $\mathrm{Chl}$ a) only presented a response to the cultivar factor. The concentrations of chlorophyll-b ( $\mathrm{Chl} \mathrm{b)} \mathrm{and} \mathrm{total} \mathrm{(Chl} \mathrm{total),}$ in their turn, presented a response to the Fe concentration factor. For the concentration of carotenoids (Carot.), there was no significant difference in the studied factors (Table 2).

The results demonstrate that the cultivars Br/Irga 409 and Irga 425 presented higher $\mathrm{Chl}$ a concentration than the cultivar Irga 424. Regardless of the P concentration tested in the nutritive solution, Fe excess in the nutritive solution caused decreases in the concentration of $\mathrm{Chl} \mathrm{b}$ and $\mathrm{Chl}$ total. Similar results were reported by Mehraban et al. (2008). In this manner, the lowest concentration of Chl total (Table 2 ), associated with the lowest $A$ (Table 1), under Fe excess conditions, may result in an imbalance in the dissipation of the excess of photon energy (Xu et al., 2007) and, consequently, reflect negatively on the proper functioning of the electron transport chain.

Furthermore, Fe, when in great availability in the cell, can favor the formation of reactive oxygen species - ROS through Fenton's reaction (Divol et al., 2013). The ROS include mainly the hydrogen peroxide $\left(\mathrm{H}_{2} \mathrm{O}_{2}\right)$, the singlet oxygen $\left({ }^{1} \mathrm{O}_{2}\right)$, the superoxide anion $\left(\mathrm{O}^{2-}\right)$, and the hydroxyl radical $\left(\mathrm{OH}^{\prime}\right)$ (Bhattacharya, 2015). When the concentration of ROS exceeds the detoxification capacity of the plant tissues, they cause damages to the lipids in the membranes, proteins, and pigments, which may result in cell death ( Sharma et al., 2012). Regarding the concentration of hydrogen peroxide $\left(\mathrm{H}_{2} \mathrm{O}_{2}\right)$, it was verified that there was an interaction between the cultivars $x \mathrm{P}$ concentration factors (Figure 1).

When subjected to $2.5 \mathrm{mg} \mathrm{L}^{-1}$ of $\mathrm{P}$, the cultivar Irga 425 presented a higher concentration of $\mathrm{H}_{2} \mathrm{O}_{2}$ in relation to the

Table 2. Stomatal conductance (Gs), intercellular $\mathrm{CO}_{2}$ concentration (Ci), lipid peroxidation (MDA), concentration of chlorophyll-a ( $\mathrm{Chl} \mathrm{a),} \mathrm{chlorophyll-b} \mathrm{(Chl} \mathrm{b),} \mathrm{total} \mathrm{chlorophyll} \mathrm{(Chl} \mathrm{total),} \mathrm{and} \mathrm{carotenoids} \mathrm{(Carot.)} \mathrm{in} \mathrm{the} \mathrm{leaves} \mathrm{of} \mathrm{three} \mathrm{rice} \mathrm{cultivars} \mathrm{(Br/Irga}$ 409, Irga 424, and Irga 425) grown under different concentrations of Fe (2, $\left.200 \mathrm{mg} \mathrm{L}^{-1}\right)$ and $\mathrm{P}\left(2.5,15 \mathrm{mg} \mathrm{L}^{-1}\right)$ in the nutritive solution.

\begin{tabular}{|c|c|c|c|c|c|c|c|}
\hline $\mathrm{Fe}$ & Gs & $\mathbf{C i}$ & MDA & $\mathrm{Chl} \mathrm{a}$ & Chl b & Chl total & Carot. \\
\hline$\left(\mathrm{mg} \mathrm{L}^{-1}\right)$ & $\left(\mathrm{mol}\right.$ of $\left.\mathrm{H}_{2} \mathrm{O} \mathrm{m}^{-2} \mathrm{~s}^{-1}\right)$ & $\left(\mu \mathrm{mol} \mathrm{CO}_{2} \mathrm{~mol}^{-1}\right)$ & (nM of MDA $\mathrm{g}^{-1}$ protein) & \multicolumn{4}{|c|}{ (mg g-1 MF) } \\
\hline 2 & $0.52 \alpha$ & $322.33 \alpha$ & $0.56 \alpha$ & $1.18 \alpha$ & $2.94 \alpha$ & $4.12 \alpha$ & $1.26 \alpha$ \\
\hline 200 & $0.32 \beta$ & $284.43 \beta$ & $0.54 \alpha$ & $1.17 \alpha$ & $0.74 \beta$ & $1.91 \beta$ & $0.43 \alpha$ \\
\hline Cultivars & & & & & & & \\
\hline $\mathrm{Br} /$ Irga 409 & $0.35 \mathrm{~B}$ & $297.36 \mathrm{~A}$ & $0.57 \mathrm{~A}$ & $1.23 \mathrm{~A}$ & $0.78 \mathrm{~A}$ & $3.27 \mathrm{~A}$ & $0.45 \mathrm{~A}$ \\
\hline Irga 424 & $0.39 \mathrm{~B}$ & $304.36 \mathrm{~A}$ & $0.58 \mathrm{~A}$ & $1.06 \mathrm{~B}$ & $0.68 \mathrm{~A}$ & $2.89 \mathrm{~A}$ & $0.41 \mathrm{~A}$ \\
\hline Irga 425 & $0.51 \mathrm{~A}$ & $308.44 \mathrm{~A}$ & $0.50 \mathrm{~B}$ & $1.25 \mathrm{~A}$ & $0.73 \mathrm{~A}$ & $3.32 \mathrm{~A}$ & $0.42 \mathrm{~A}$ \\
\hline
\end{tabular}

Means followed by different letters differ significantly at $5 \%$ by the Scott Knott test. Uppercase letters compare cultivars. Greek letters compare the same cultivar at different Fe concentrations $\left(2,200 \mathrm{mg} \mathrm{L}^{-1}\right)$. 


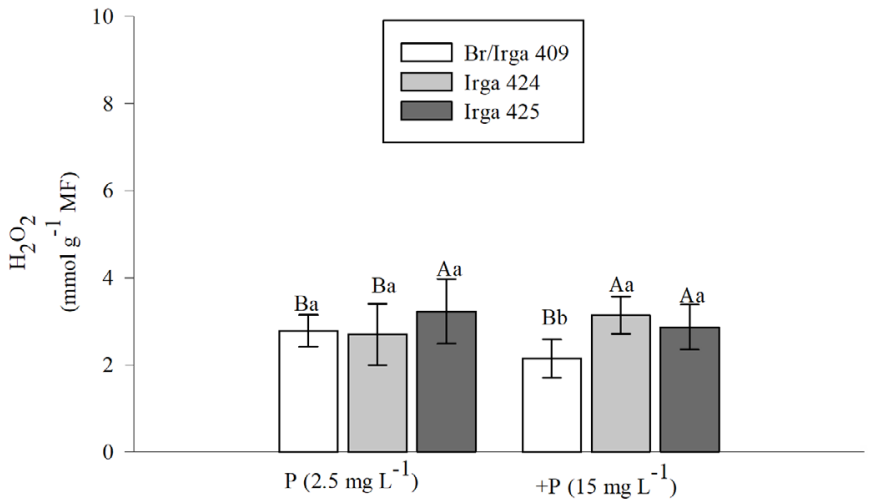

* Means followed by different letters differ significantly by the Scott Knott test at $5 \%$ of error probability. Uppercase letters compare cultivars within the same treatment. Lowercase letters compare the same cultivar under different $P$ concentrations $\left(2,15 \mathrm{mg} \mathrm{L}^{-1}\right)$.

Figure 1. Changes in the concentration of hydrogen peroxide in the leaves of three rice cultivars grown under different concentrations of $\mathrm{P}\left(2.5,15 \mathrm{mg} \mathrm{L}^{-1}\right)$ in the nutritive solution.

remaining cultivars. On the other hand, with the increase in $\mathrm{P}$ concentration, only the cultivar $\mathrm{Br} / \mathrm{Irga} 409$ presented a reduction in the concentration of $\mathrm{H}_{2} \mathrm{O}_{2}$ in relation to the remaining cultivars (Figure 1 ).

Plant cells possess an enzymatic mechanism that eliminates or reduces the harmful effects of the ROS, such as the superoxide dismutase (SOD) and guaiacol peroxidase (POD). For the enzymes of the antioxidant system, superoxide dismutase (SOD), and guaiacol peroxidase (POD), there was an interaction between the cultivars $\times \mathrm{P}$ concentrations $\mathrm{x} F$ concentrations factors (Table 3).

When exposed to a low Fe concentration associated with a high $\mathrm{P}$ concentration, the cultivar Irga 424 presented higher SOD activity, compared to the remaining cultivars. On the other hand, when subjected to $200 \mathrm{mg} \mathrm{L}^{-1}$ of $\mathrm{Fe}$, the cultivar Irga 425 presented higher SOD activity in relation to the two remaining cultivars (Table 3 ).

When comparing the SOD activity in the Fe control treatment $\left(2 \mathrm{mg} \mathrm{L}^{-1}\right)$ at different $\mathrm{P}$ concentrations ( 2.5 and $\left.15 \mathrm{mg} \mathrm{L}^{-1}\right)$, it is verified that the cultivar Irga 424 presented an increment in SOD activity with the increase in the concentration of $\mathrm{P}$ in the nutritive solution (Table 3). Regarding the plants subjected to Fe excess, only the cultivar Irga 425 presented an increment in SOD activity with the increase in the concentration of $\mathrm{P}$ (Table 3 ).

When exposed to $\mathrm{Fe}$ excess associated with a low $\mathrm{P}$ concentration, the cultivar $\mathrm{Br} /$ Irga 409 presented a higher value in SOD activity compared to the plants subjected to the control treatment [Fe/P]. On the other hand, when increasing the concentration of $\mathrm{P}$ under Fe excess conditions, the cultivar Irga 425 was the only one that presented increments of $62.37 \%$ in SOD activity in relation to the control treatment [Fe/+P] (Table 3).

With the increase in $\mathrm{P}$ concentration associated with the Fe control treatment, the cultivar $\mathrm{Br} / \mathrm{Irga} 409$ presented a higher POD activity value than the two other cultivars. On the other hand, when exposed to $200 \mathrm{mg} \mathrm{L}^{-1}$ of Fe associated to a low $\mathrm{P}$ concentration, the cultivar $\mathrm{Br} / \mathrm{Irga} 409$, followed by the Irga 425, presented higher POD activity than the cultivar Irga 424. However, with the increase in P concentration, under Fe excess conditions, (200 $\left.\mathrm{mg} \mathrm{L}^{-1}\right)$, only the cultivar Irga 425 presented a reduction in POD activity (Table 3).

Considering the activity of the POD enzyme in the $\mathrm{Fe}$ control treatment $\left(2 \mathrm{mg} \mathrm{L}^{-1}\right)$ at different $\mathrm{P}$ concentrations ( 2.5 and $15 \mathrm{mg} \mathrm{L}^{-1}$ ), it was observed that the cultivar $\mathrm{Br} / \mathrm{Irga} 409$ was the only one that increased POD activity with the increase in the concentration of $\mathrm{P}$ in the nutritive solution $[\mathrm{Fe} /+\mathrm{P}]$ (Table 3 ). In this condition, the cultivar Irga 424 reduced POD activity. When compared to plants subjected to Fe excess and low $\mathrm{P}$ concentration $[\mathrm{Fe} / \mathrm{P}]$, the cultivar Irga 424 presented an increase in POD activity with the increase in the concentration of $\mathrm{P}[+\mathrm{Fe} /+\mathrm{P}]$ (Table 3$)$.

When compared to the control treatment $[\mathrm{P} / \mathrm{Fe}]$, the cultivars Br/Irga 409 and Irga 425 presented significant increases in POD activity when exposed to $200 \mathrm{mg} \mathrm{L}^{-1}$ of Fe at a low $\mathrm{P}$ concentration [+Fe/P]. On the other hand, with the increase in the concentration of $\mathrm{P}$ associated with the excess of $\mathrm{Fe}[+\mathrm{P} /+\mathrm{Fe}]$, all cultivars presented increments in $\mathrm{POD}$ activity (Table 3 ).

Regarding the POD, this protein catalyzes the conversion reaction of $\mathrm{H}_{2} \mathrm{O}_{2}$ into $\mathrm{H}_{2} \mathrm{O}$ (Barbosa et al., 2014). In general, although the cultivars presented increased POD activity (Table 3) in Fe toxicity conditions associated with the

Table 3. Enzymatic activity of superoxide dismutase (SOD) and guaiacol peroxidase (POD) in three rice cultivars (Br/lrga 409, Irga 424, and Irga 425) grown under different concentrations of Fe $\left(2,200 \mathrm{mg} \mathrm{L}^{-1}\right)$ and $\mathrm{P}\left(2.5,15 \mathrm{mg} \mathrm{L}^{-1}\right)$ in the nutritive solution.

\begin{tabular}{|c|c|c|c|c|}
\hline & \multicolumn{2}{|c|}{$\mathrm{Fe}\left(2 \mathrm{mg} \mathrm{L}^{-1}\right)$} & \multicolumn{2}{|c|}{$+\mathrm{Fe}\left(200 \mathrm{mg} \mathrm{L}^{-1}\right)$} \\
\hline & $P\left(2.5 \mathrm{mg} \mathrm{L}^{-1}\right)$ & $+P\left(15 \mathrm{mg} \mathrm{L}^{-1}\right)$ & $P\left(2.5 \mathrm{mg} \mathrm{L}^{-1}\right)$ & $+P\left(15 \mathrm{mg} \mathrm{L}^{-1}\right)$ \\
\hline \multicolumn{5}{|c|}{ SOD (Umg ${ }^{-1}$ of protein) } \\
\hline $\mathrm{Br} /$ Irga 409 & $9.44 \mathrm{Aa \beta}$ & $11.90 \mathrm{Ba \alpha}$ & $18.41 \mathrm{Aa \alpha}$ & $15.18 \mathrm{Ba \alpha}$ \\
\hline Irga 424 & $14.90 \mathrm{Ab} \alpha$ & 23.31 Aa $\alpha$ & $13.23 \mathrm{Aa \alpha}$ & $13.33 \mathrm{Ba \alpha}$ \\
\hline Irga 425 & $10.01 \mathrm{Aa \alpha}$ & $14.11 \mathrm{Ba \beta}$ & $16.16 \mathrm{Ab} \alpha$ & $42.95 \mathrm{Aa \alpha}$ \\
\hline \multicolumn{5}{|c|}{ POD (mmol tetraguaiacol $\mathrm{min}^{-1} \mathrm{mg}^{-1}$ of protein) } \\
\hline $\mathrm{Br} /$ Irga 409 & $1.93 \mathrm{Ab} \beta$ & $3.90 \mathrm{Aa} \beta$ & 4.98 Aa $\alpha$ & 5.98 Aa $\alpha$ \\
\hline Irga 424 & $2.21 \mathrm{Aa} \alpha$ & $0.77 \mathrm{Bb} \beta$ & $1.40 \mathrm{Cb} \alpha$ & 5.54 Aa $\alpha$ \\
\hline Irga 425 & $1.80 \mathrm{Aa \beta}$ & 0.93 ваß & 3.27 Ba $\alpha$ & 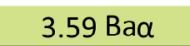 \\
\hline
\end{tabular}

Means followed by different letters differ significantly by the Scott Knott test at $5 \%$ of error probability. Uppercase letters compare cultivars within the same treatment $(\mathrm{P} / \mathrm{Fe},+\mathrm{P} / \mathrm{Fe}$ $\mathrm{P} /+\mathrm{Fe},+\mathrm{P} /+\mathrm{Fe})$. Lowercase letters compare the same cultivar in the $\mathrm{P}$ treatments at the same Fe concentration $(\mathrm{P} / \mathrm{Fe},+\mathrm{P} / \mathrm{Fe} ; \mathrm{P} /+\mathrm{Fe},+\mathrm{P} /+\mathrm{Fe})$. Greek letters compare the same cultivars at different Fe concentrations and at the same concentration of $\mathrm{P}(\mathrm{P} / \mathrm{Fe}, \mathrm{P} /+\mathrm{Fe} ;+\mathrm{P} / \mathrm{Fe},+\mathrm{P} /+\mathrm{Fe})$. 
increase in $\mathrm{P}$ concentration $[+\mathrm{Fe} /+\mathrm{P}]$, Xiao et al. (2010), when studying the activity of antioxidant enzymes in Pilea sinofasciata subjected to different $P$ concentrations in the soil, verified that, under high $P$ concentration, there was a higher activity of the SOD and POD enzymes. According to Becker \& Asch (2005), the activities of the SOD-POD enzymes are mostly responsible for the prevention of oxidative stress in rice leaves.

For the variable of shoot dry matter production (MSPA), there was a response of the interaction between cultivars $x P$ concentration and cultivars $x$ Fe concentration (Figure $2 A$ and $2 B$ ).

Regardless of the tested Fe concentrations, the cultivars did not differ from each other regarding the production of MSPA. However, when exposed to $200 \mathrm{mg} \mathrm{L}^{-1}$ of Fe, only the cultivar Br/Irga 409 presented a reduced production of MSPA (Figure 2A), demonstrating greater sensitivity to Fe toxicity (Vahl, 1991; Nava \& Bohen, 2002; Sosbai, 2018).

In the presence of low $\mathrm{P}$, the cultivar Irga 424 presented higher production of MSPA than the other two cultivars. However, with the increase in $\mathrm{P}$ concentration, the cultivar Irga 424 presented lower production of MSPA, resulting in lower values when compared to the plants subjected to the control treatment with $2.5 \mathrm{mg} \mathrm{L}^{-1}$ of $\mathrm{P}$ (Figure $2 \mathrm{~B}$ ).

Regardless of the tested Fe concentrations, all cultivars did not differ from each other regarding the production of MSPA. However, when exposed to $200 \mathrm{mg} \mathrm{L}^{-1}$ of Fe, only the cultivar $\mathrm{Br} /$ Irga 409 presented a reduced production of MSPA (Figure $2 \mathrm{~A})$, demonstrating greater sensitivity to Fe toxicity (Vahl, 1991; Nava \& Bohen, 2002; Sosbai, 2018).

In the presence of low $\mathrm{P}$, the cultivar Irga 424 presented higher production of MSPA than the two other cultivars. However, with the increase in $\mathrm{P}$ concentration, the cultivar Irga 424 presented lower production of MSPA, resulting in lower values when compared to the plants subjected to the control treatment with $2.5 \mathrm{mg} \mathrm{L}^{-1}$ of $\mathrm{P}$ (Figure $2 \mathrm{~B}$ ).

The production of root dry matter per plant (MSR) presented an interaction between cultivars $x$ Fe concentrations x P concentrations (Table 4). There were significant differences between cultivars regarding the production of MSR in the Fe control condition ( $2 \mathrm{mg} \mathrm{L}^{-1}$ ). In this condition, the cultivars $\mathrm{Br}$ / Irga 409 and Irga 425 presented higher production of MSR when exposed to low $P$ concentration (Table 4). With the increase in $\mathrm{P}$ concentration, the cultivar $\mathrm{Br} / \mathrm{Irga} 409$ presented lower production of MSR than the other cultivars.

In the Fe control treatment $\left(2 \mathrm{mg} \mathrm{L}^{-1}\right)$ combined with different $\mathrm{P}$ concentrations ( 2.5 and $\left.15 \mathrm{mg} \mathrm{L}^{-1}\right)$, it was verified that the cultivar $\mathrm{Br} /$ Irga 409 presented a decrease of $42.70 \%$ in the production of MSR when the $P$ concentration was increased in the nutritive solution [Fe/+P]. The cultivar Irga 424 , in this condition, presented increments of $57.76 \%$ in the production of MSR. Grossman \& Rice (2012) verified that barley plants presented a higher root mass ratio under low $P$ availability. The tight correlation between the $P$ absorption with the root morphological characteristics suggest that $P$ availability is locally perceived and acts as a signal for the formation of lateral roots (Péret et al., 2011; Niu et al. 2012).

When exposed to $200 \mathrm{mg} \mathrm{L}^{-1}$ of $\mathrm{Fe}$, regardless of the $P$ concentration, all cultivars presented reductions in the MSR

Table 4. Root dry matter (MSR) of three rice cultivars $(\mathrm{Br} /$ Irga 409, Irga 424, and Irga 425) grown under different concentrations of Fe $\left(2,200 \mathrm{mg} \mathrm{L}^{-1}\right)$ and $\mathrm{P}\left(2.5,15 \mathrm{mg} \mathrm{L}^{-1}\right)$ in the nutritive solution.

\begin{tabular}{|c|c|c|c|c|}
\hline & \multicolumn{2}{|c|}{$\mathrm{Fe}\left(2 \mathrm{mg} \mathrm{L}^{-1}\right)$} & \multicolumn{2}{|c|}{$+\mathrm{Fe}\left(200 \mathrm{mg} \mathrm{L}^{-1}\right)$} \\
\hline & $\begin{array}{c}P \\
\left(2.5 \mathrm{mg} \mathrm{L}^{-1}\right)\end{array}$ & $\begin{array}{c}+P \\
\left(15 \mathrm{mg} \mathrm{L}^{-1}\right)\end{array}$ & $\begin{array}{c}P \\
\left(2.5 \mathrm{mg} \mathrm{L}^{-1}\right)\end{array}$ & $\begin{array}{c}+P \\
\left(15 \mathrm{mg} \mathrm{L}^{-1}\right)\end{array}$ \\
\hline & \multicolumn{4}{|c|}{ MSR (g plant ${ }^{-1}$ ) } \\
\hline $\mathrm{Br} / \mathrm{Irga} 409$ & $2.18 \mathrm{Aa} \alpha$ & $1.25 \mathrm{Bba}$ & $0.25 \mathrm{Aa} \beta$ & $0.19 \mathrm{Aa \beta}$ \\
\hline Irga 424 & 1.21 Bba & $1.90 \mathrm{Aa} \alpha$ & $0.21 \mathrm{Aa} \beta$ & $0.21 \mathrm{Aa \beta}$ \\
\hline Irga 425 & $2.15 \mathrm{Aa} \alpha$ & $1.80 \mathrm{Aa} \alpha$ & $0.21 \mathrm{Aa} \beta$ & $0.21 \mathrm{Aa} \beta$ \\
\hline
\end{tabular}

Means followed by different letters differ significantly by the Scott Knott test at $5 \%$ of error probability. Uppercase letters compare cultivars within the same treatment $(\mathrm{P} / \mathrm{Fe}$, $+\mathrm{P} / \mathrm{Fe}, \mathrm{P} /+\mathrm{Fe},+\mathrm{P} /+\mathrm{Fe})$. Lowercase letters compare the same cultivar in the $\mathrm{P}$ treatments at the same $\mathrm{Fe}$ concentration $(\mathrm{P} / \mathrm{Fe},+\mathrm{P} / \mathrm{Fe} ; \mathrm{P} /+\mathrm{Fe},+\mathrm{P} /+\mathrm{Fe})$. Greek letters compare the same cultivar at different Fe concentrations, and at the same concentration of $\mathrm{P}(\mathrm{P} / \mathrm{Fe}$, $\mathrm{P} /+\mathrm{Fe} ;+\mathrm{P} / \mathrm{Fe},+\mathrm{P} /+\mathrm{Fe})$.
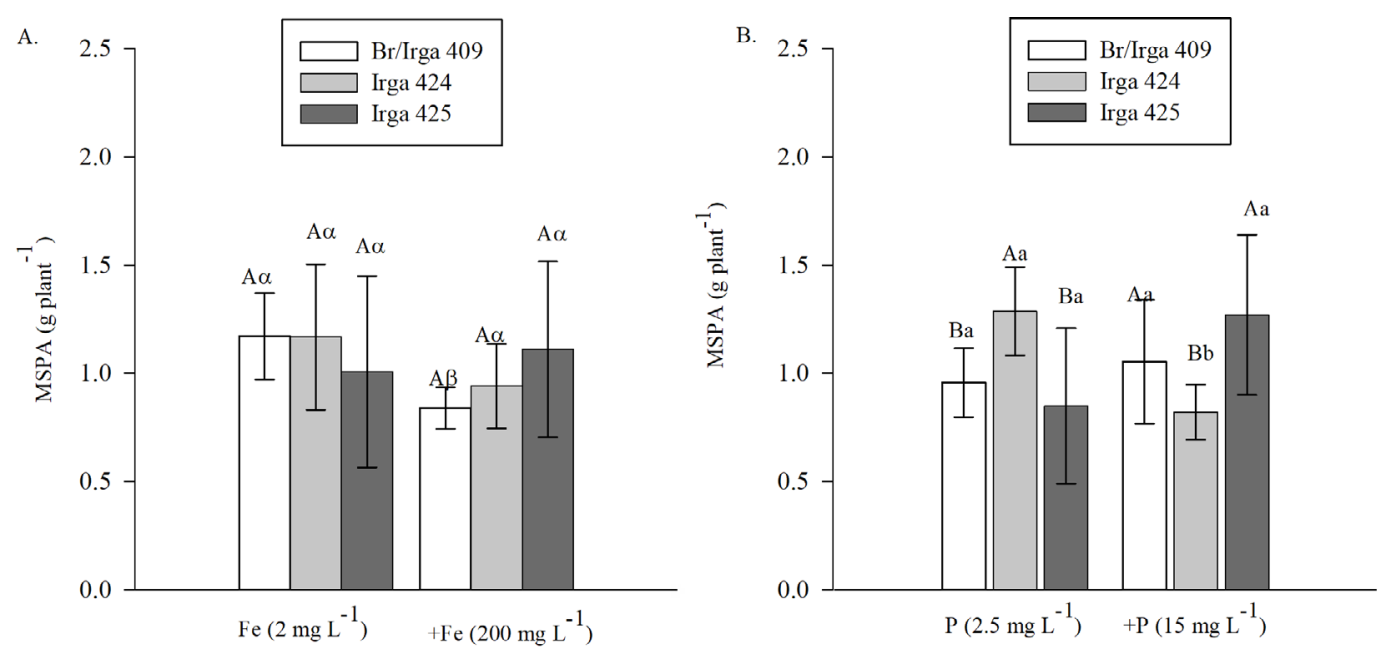

*Means followed by different letters differ significantly by the Scott Knott test at $5 \%$ of error probability. Uppercase letters compare cultivars within the same treatment. Greek letters compare the same cultivar at different Fe concentrations $\left(2,200 \mathrm{mg} \mathrm{L}^{-1}\right)$. Lowercase letters compare the same cultivar in the treatments with $\mathrm{P}$ concentrations $\left(2.5,15 \mathrm{mg} \mathrm{L}^{-1}\right)$.

Figure 2. Shoot dry matter (MSPA) of three rice cultivars grown under different concentrations of Fe $\left(2,200\right.$ mg $\left.L^{-1}\right)$ and $P(2.5$, $15 \mathrm{mg} \mathrm{L}^{-1}$ ) in the nutritive solution. 
when compared to the plants subjected to $2 \mathrm{mg} \mathrm{L}^{-1}$ of Fe (Table 4). The excess of Fe causes cell collapse in the roots, disorganization of the vascular cylinder, and alterations in the differentiation patterns (Zhang et al., 2011; Siqueira-Silva et al., 2012), which, consequently, influence negatively the growth and development of roots.

\section{Conclusions}

The addition of $P$ mitigates the deleterious effects of $\mathrm{Fe}$ toxicity through effects in the system of antioxidant enzymes, and such responses vary according to the cultivars studied.

All cultivars presented some degree of sensitivity to Fe excess, which compromised the net $\mathrm{CO}_{2}$ assimilation rate, stomatal conductance, and reductions in the concentrations of chlorophyll,

The cultivar $\mathrm{Br} / \mathrm{Irga} 409$ presented greater sensitivity to $\mathrm{Fe}$ toxicity in relation to the remaining cultivars (Irga 424 and Irga 425).

The cultivar Irga 425 demonstrated greater tolerance to Fe excess when associated with the increase of $P$ availability, which increased with the higher responses of photosynthesis and antioxidant enzymatic activity (superoxide dismutase).

\section{Literature Cited}

Ahn, T.; Oke, M.; Schofield, A.; Paliyath, G. Effects of phosphorus fertilizer supplementation on antioxidant enzyme activities in tomato fruits. Journal of Agricultural and Food Chemistry, v.3, n. 5, p.1539- 45, 2005. https://doi.org/10.1021/jf040248y.

Andrade, W.E.B.; Amorim Neto, S.; Vasconcellos, J.F.F. Identificação de toxidez por ferro em solos da baixada campista, norte fluminense. Informações Tecnológica on line, n. 47, 2015. http:// www.pesagro.rj.gov.br/downloads/infonline/online47.pdf. 01 Apr. 2020.

Barbosa, R.M.; Silva, S.M.A.; Willadino, L.; Ulisses, C. Camara, T.R. Geração e desintoxicação enzimática de espécies reativas de oxigênio em plantas. Ciência Rural, v.44, n.6, p. 453-46, 2014. https://doi.org/10.1590/S0103-84782014000300011.

Becker, M.; Asch, F. Iron toxicity in rice- Conditions and management concepts. Journal of Plant Nutrition and Soil Science, v.168, n.4, p. 58-573, 2015. https://doi.org/10.1002/jpln.200520504.

Bhattacharya, S. Reactive oxygen species and cellular defense system. In: Rani, V.; Yadav, U. C. S. (Eds.). Free radicals in human health and disease. New Delhi: Springer, 2015. p. 17-29. https:// doi.org/10.1007/978-81-322-2035-0_2.

Briat, J.F.; Ravet, K.; Arnaud, N.; Duc, C.; Boucherez, J.; Touraine, B.; Cellier, F.; Gaymard, F. New insights into ferritin synthesis and function highlight a link between iron homeostasis and oxidative stress in plants. Annals of Botany, v. 105, n.5, p. 811-22, 2009. https://doi.org/10.1093/aob/mcp128.

Curie, C.; Cassin, G.; Couch, D.; Divol, F.; Higuchi, K.; Le Jean, M.; Misson, J.; Schikora, A.; Czernic, P.; Mari, S. Metal movement within the plant: contribution of nicotianamine and yellow stripe 1-like transporters. Annals of Botany, v. 103, n.1, p. 1-11, 2009. https://doi.org/10.1093/aob/mcn207.
Divol, F.; Couch, D.; Conéjéro, G.; Roschzttardtz, H.; Mari, S.; Curie, C. The Arabidopsis yellow stripe like 4 and 6 transporters control iron release from the chloroplast. The Plant Cell, v.25, n.3, p. 1040-55, 2013. https://doi.org/10.1105/tpc.112.107672.

El-Moshaty, F.I.B.; Pike, S.M.; Novacky, A.J.; Sehgal, O.P. Lipid Peroxidation and superoxide production in cowpea (Vigna unguiculata) leaves infected with tobacco ringspot virus or southern bean mosaic virus. Physiological and Molecular Plant Pathology, v.43, n.2, p.109-119, 1993. https://doi.org/10.1006/ pmpp.1993.1044.

Giannopolitis, C.N.; Ries, S.K. Superoxide dismutases: I. occurrence in higher plants. Plant Physiology, v.59, n.2, p.309-314, 1977. https://doi.org/10.1104/pp.59.2.309.

Grossman, J.D., Rice, K.J. Evolution of root plasticity responses to variation in soil nutrient distribution and concentration. Evolutionary Applications, v. 5, n. 8, p. 850-857, 2012. https:// doi.org/10.1111/j.1752-4571.2012.00263.x.

Hiscox, J.D.; Israelstam, G.F. A method for the extraction of chlorophyll from leaf tissue without maceration. Canadian Journal of Botany, v.57, n.12, p.1132-1334, 1979 . https://doi.org/10.1139/b79163.

Howeler, R. Iron-induced oranging disease of rice in relation to physico chemical changes in a flooded oxisol1. Soil Science Society of America Journal, v. 37, n.6, p.898-903, 1973. https:// doi.org/10.2136/sssaj1973.03615995003700060030x.

Huang, C.Y.; Huang, C.Y.; Roessner, U.; Eickmeier, I.; Genc, Y.; Callahan, D.L.; Shirley, N.; Langridge, P.; Bacic, A. Metabolite profiling reveals distinct changes in carbon and nitrogen metabolism in phosphate-deficient barley plants (Hordeum vulgare L.). Plant \& Cell Physiology, v.49, n.5, p. 691-703, 2008. https://doi. org/10.1093/pcp/pcn044 .

Jeong, J.; Guerinot, M.L. Homing in on iron homeostasis in plants. Trends in Plant Science, v.14, n.5, p. 280-285, 2009. https://doi. org/10.1016/j.tplants.

Lichtenthaler, H.K. Clorophylls and carotenoids: Pigments of photosynthetic biomembranes. Methods Enzymology, v.148, p.350-382, 1987. https://doi.org/10.1016/0076-6879(87)480361.

Loreto, F.; Velikova, V. Isoprene produced by leaves protects the photosynthetic apparatus against ozone damage, quenches ozone products, and reduces lipid peroxidation of cellular membranes. Plant Physiology, v.127, n.4, p.1781-1787, 2001. https://doi.org/10.1104/pp.010497.

Majerus, V.; Bertin, P.; Lutts, S. Abscisic acid and oxidative stress implications in overall ferritin synthesis by African rice (Oryza Glaberrima steud.) seedlings exposed to short term iron toxicity. Plant Soil, v. 324, p. 253-265, 2009. https://doi.org/10.1007/ s11104-009-9952-x.

Mehraban, P.; Zadeh, A.A.; Sadeghpour, H.R. Iron toxicity in rice (Oryza sativa L.) under different potassium nutrition. Asian Journal of Plant Sciences, v.7, n.3, p.251-259, 2008. https://doi. org/10.3923/ajps.2008.251.259.

Nava, G.; Bohnen, H. Oxidação de ferro em raízes de dois cultivares de arroz em solução de solo inundado. Revista Brasileira de Ciência do Solo, v. 26, n.2, p. 325-332, 2002. https://doi.org/10.1590/ S0100-06832002000200005. 
Niu, Y.F.; Chai, R.S.; Jin, G.L.; Wang, H.; Tang, C.X.; Zhang, Y.S. Responses of root architecture development to low phosphorus availability: a review. Annals of Botany, v. 112, n. 2, p. 391-408, 2012. https://doi.org/10.1093/aob/mcs285.

Pandey, R.; Zinta, G.; Elgawad, H.; Ahmad, A.; Jain, V.; Janssens, I.A. Physiological and molecular alterations in plants exposed to high $\left[\mathrm{CO}_{2}\right]$ under phosphorus stress. Biotechnology Advances, v.33, p.303-16, 2015. https://doi.org/10.1016/j.biotechadv.

Pereira, E.G.; Oliva, M.A.; Rosado-Souza, L.; Mendes, G.C.; Colares, D.S.; Stopato, C,H.; Almeida, A.M. . Iron excess affects rice photosynthesis through stomatal and non- stomatal limitations. Plant Science, v.201-202, p. 81-92, 2014. https://doi. org/10.1016/j.plant sci.2012.12.003.

Péret, B.; Clément, M.; Nussaume, L.; Desnos, T. Root developmental adaptation to phosphate starvation: better safe than sorry. Trends in Plant Sciences, v.16, n.8. p.442-450, 2011. https://doi. org/10.1016/j.tplants.2011.05.006.

Pezeshki, S.R.; Delaune, R.D. Soil oxidation-reduction in wetlands and its impact on plant functioning. Biology, v. 1, n.2, p.196-221, 2012. https://doi.org/10.3390/biology1020196.

Pieters, A.J.; Paul, M.J.; Lawlor, D.W. Low sink demand limits photosynthesis under $\mathrm{P}(\mathrm{i})$ deficiency. Journal of Experimental Botany, v.52, n.358, p.1083-1091, 2001. https://doi.org/10.1093/ jexbot/52.358.1083.

Sahrawat, K. Reducing iron toxicity in lowland rice with tolerant genotypes and plant nutrition. Plant Stress, v.4, n. 2, p. 70-7, 2010. http://oar.icrisat.org/166/1/nset1.pdf. 09 Apr. 2020.

Schroeder, J.I.; Allen, G.J.; Hugouvieux, V.; Kwak, J.M.; Waner, D. Guard cell signal transduction. Annual Review of Plant Physiology and Plant Molecular Biology, v.52, p.627-658, 2001. https://doi. org/10.1146/annurev.arplant.52.1.627.

Shahandeh, H.; Hossner, L.R.; Turner, F.T. Phosphorus relationships to manganese and iron in rice soils. Soil Science, v. 168, n.7, p. 489-500, 2003. https://doi.org/10.1097/01. ss.0000080334.10341.6a.

Sharma, P.; Jha, A.B.; Dubey, R.S.; Pessarakli, M. Reactive oxygen species, oxidative damage, and antioxidative defense mechanism in plants under stressful conditions. Journal of Botany, v.2012, article 217037, 2012. https://doi.org/10.1155/2012/217037.

Silveira, V.C.; Oliveira, A.P.; Sperotto, R.A.; Espindola, L.S.; Amaral, L.D.; Johnny, F.; Cunha, J.B.; Fett, J.P. Influence of iron on mineral status of two rice (Oryza sativa L.) cultivars. Brazilian Journal of Plant Physiology, v.19, n.2, p.127-139, 2007. https://doi. org/10.1590/S1677-04202007000200005.

Siqueira-Silva, A.; Luzimar, C.S.; Aristéa, A.A.; Oliva, M.A. Iron plaque formation and morphoanatomy of roots from species of restinga subjected to excess iron. Ecotoxicology and Environmental, v. 78, p. 265-275, 2012. https://doi.org/10.1016/j.ecoenv.2011.11.030.
Sociedade Sul-Brasileira de Arroz Irrigado - Sosbai. Arroz irrigado: recomendações técnicas da pesquisa para o Sul do Brasil. In: Reunião Técnica da Cultura do Arroz Irrigado, 32., 2018, Farroupilha. Cachoeirinha: Sosbai, 2018. 77p. http://www. sosbai.com.br/docs/Boletim_RT_2018.pdf. 09 Apr. 2020.

Sousa, R.O.; Camargo, F.A.O.; Vahl, L.C. 2006. Solos alagados-Reações de Redox. In: Meurer, E.J. (Ed.). Fundamentos de química do solo. 3.ed. Porto Alegre: Ed. Evangraf, 2006. 185-211p.

Vahl, L.C. Toxidez de ferro em genótipos de arroz irrigado por alagamento. Porto Alegre: Universidade Federal do Rio Grande do Sul, 1991. 167p. Tese Doutorado.

van Oort, P.A.J. Mapping abiotic stresses for rice in Africa: Drought, cold, iron toxicity, salinity and sodicity. Field Crops Research, v. 219, p. 55-75, 2018. https://doi.org/10.1016/j.fcr.2018.01.016.

Vigani, G.; Gianpiero, V.; Graziano, Z.; Khurram, B.; Katrin, P.; JeanFrancois B. Cellular iron homeostasis and metabolism in plant. Front in Plant Science, v.4, article 490, 2013. https://doi. org/10.3389/fpls.2013.00490.

Xiao, F. Z.; Chun Quan, Z.; Xu, S.Z.; Shao, J.Z.; Ren F.S. Ethylene is involved in root phosphorus remobilization in rice (Oryza sativa L.) by regulating cell-wall pectin and enhancing phosphate translocation to shoots. Annals of Botany, v.118, n.4, p.645-653, 2016. https://doi.org/10.1093/aob/mcw044.

Xu, H.X.; Weng, X.Y.; Yang, Y. Effect of phosphorus deficiency on the photosynthetic characteristics of rice plants. Russian Journal of Plant Physiology, v.54, p.741-748, 2007. https://doi. org/10.1134/S1021443707060040.

Yadavalli, V.; Neelam, S.; Rao, A.S.; Reddy, A.R. \& Subramanyam, R. Differential degradation of photosystem I subunits under iron deficiency in rice. Journal of Plant Physiology, v.169, n.8, p.753759, 2012. https://doi.org/10.1016/j.jplph.2012.02.008.

Yoshida, S.; Forno, D.A.; Cock, J.H.; Gomez, A. Laboratory manual for physiological studies of rice. 3.ed. Manila: The International Rice Research Institute, 1976.83 p. http://books.irri.org/9711040352_ content.pdf. 19 Mar. 2020.

Zeraik, A.E. ; Souza, F.S.; Fatibello-Filho, O.; Leite, O.D. Desenvolvimento de um spot test para o monitoramento da atividade da peroxidase em um procedimento de purificação. Química Nova, v.31, n4, p.731-734, 2008. https://doi. org/10.1590/S0100-40422008000400003.

Zhang, Y.; Zheng, G.H.; Liu, P.; Song, J.M.; Xu, G.D.; Cai, M. Z. Morphological and physiological responses of root tip cells to $\mathrm{Fe}^{2+}$ toxicity in rice. Acta Physiologiae Plantarum, v. 33, p. 683689, 2011. https://doi.org/10.1007/s11738-010-0590-y.

Zhu, Z.; Wei, G.; JLi, J.; Qian, Q.; Yu, J. Silicon alleviates salt stress and increases antioxidant enzymes activity in leaves of salt-stressed cucumber (Cucumis sativus L.), Plant Science, v.167, n.3, p.527533, 2004. https://doi.org/10.1016/j.plantsci.2004.04.020. 